(C) 2017, Elsevier. Licensed under the Creative Commons AttributionNonCommercial-NoDerivatives 4.0 International

http://creativecommons.org/licenses/by-nc-nd/4 .0/

\title{
Service implementation in manufacturing: An organisational transformation perspective
}

\author{
Dr. Oscar F. Bustinza*t, Dr. Ferran Vendrell-Herrero $\uparrow+$ and Prof. Tim Baines $\uparrow$, \\ $\neq$ Universidad de Granada, oscarfb@ugr.es \\ tt University of Birmingham, f.vendrell-herrero@bham.ac.uk \\ †Aston Business School, Aston University, t.baines@aston.ac.uk
}

\begin{abstract}
The topic of servitization of manufacturing continues to gain attention from both the engineering and business research communities. As a consequence, the conceptual foundations of servitization are now becoming better established, and attention is focusing on the processes through which manufacturers go to develop innovative service capabilities that enable them to successfully compete through services. This Special Issue sets out to focus on these transformation processes. In this introductory article we review the selected articles that comprise this Special Issue. We provide a framework to contextualize and understand the research findings reported in the Special Issue and reflect on the contributions of the research to the theory and practice of servitization. Through this process we seek to consolidate the stateof-the-art in this area and identify important, challenging, but potentially fruitful topics for future studies.
\end{abstract}

Key words: Servitization, Transformation, Service implementation

* Corresponding author: Oscar F. Bustinza (Faculty of Economics, University of Granada, 18071 Granada, Spain, Phone: +34958241000 (Ext. 20177), Fax:+34958246222, Email: oscarfb@ugr.es) 


\section{Introduction - the servitization landscape}

Today more and more manufacturers are competing, to a greater or lesser extent, through a portfolio of services (Crozet and Millet, 2017). They are leveraging their business strategies on the capability enabled by technological innovation to allow a better engagement with customers and suppliers through the implementation of services, in addition to product offerings (Cusumano, Kahl, and Suarez, 2015). Different strategies can be pursued for achieving this. Some manufacturers build their services business by offering an ever greater variety of intermediate services, such as maintenance, condition monitoring, overhaul or repair, and remanufacturing (Baines and Lightfoot, 2013). Others are innovating more advanced services such as Power-by-the-Hour (Rolls-Royce), Document Management (Xerox) and Trucknology (MAN Bus and Truck). Both forms of services can generate growth in revenue and profit for the host manufacturer (Lee et al., 2016), but the transformation pathways for achieving these can differ significantly (Kindström, 2010; Gebauer et al., 2012). This Special Issue addresses why and how manufacturing organisations move into services and the implications of doing so.

Servitization pathways can be expressed in various ways, with one popular approach being to link to the extension of product life-cycles (Figure 1). For example, a product-centric firm may compete without developing and delivering any product-related services, and accept that market share may reduce as the product lifecycle matures and competitors' offer starts to be more attractive to consumers. Alternatively, product incremental innovation may be applied to extend the product lifecycle and continuously innovate to maintain the market share (Lee and Malerba, 2017). A third strategic option is to extend the product lifecycle through the inclusion of services (Cusumano et al., 2015).

Service implementation frequently involves technology-enabled business models developed through in-depth understanding of customers' needs (Bustinza et al., 2017). Advanced services in particular lock in consumers for long periods of time and may increase profit margin (Visnjic, Wiengarten, and Neely, 2016). However, the inclusion of services is not a risk free strategy as the shift from offering products to offering products and services is complex and may damage shareholder returns in the short run (Suarez, Cusumano, and Kahl, 2013; Benedettini, Neely, and Swink, 2015). On top of this, advanced services require holistic organisational transformation (Tukker, 2004; Ulaga and Reinartz, 2011; Baines and Lightfoot, 2013; Baines et al., 2017). However, the potential uncertainties involved in such transformation could explain why product firms in some leading industries show reluctance to transform their 
organisations towards a service-oriented business (Financial Times, 2017), and why General Electric and Siemens are seeking to develop complex cloud platforms to support and guide small and medium manufacturers during their service journey (Wall Street Journal, 2017).

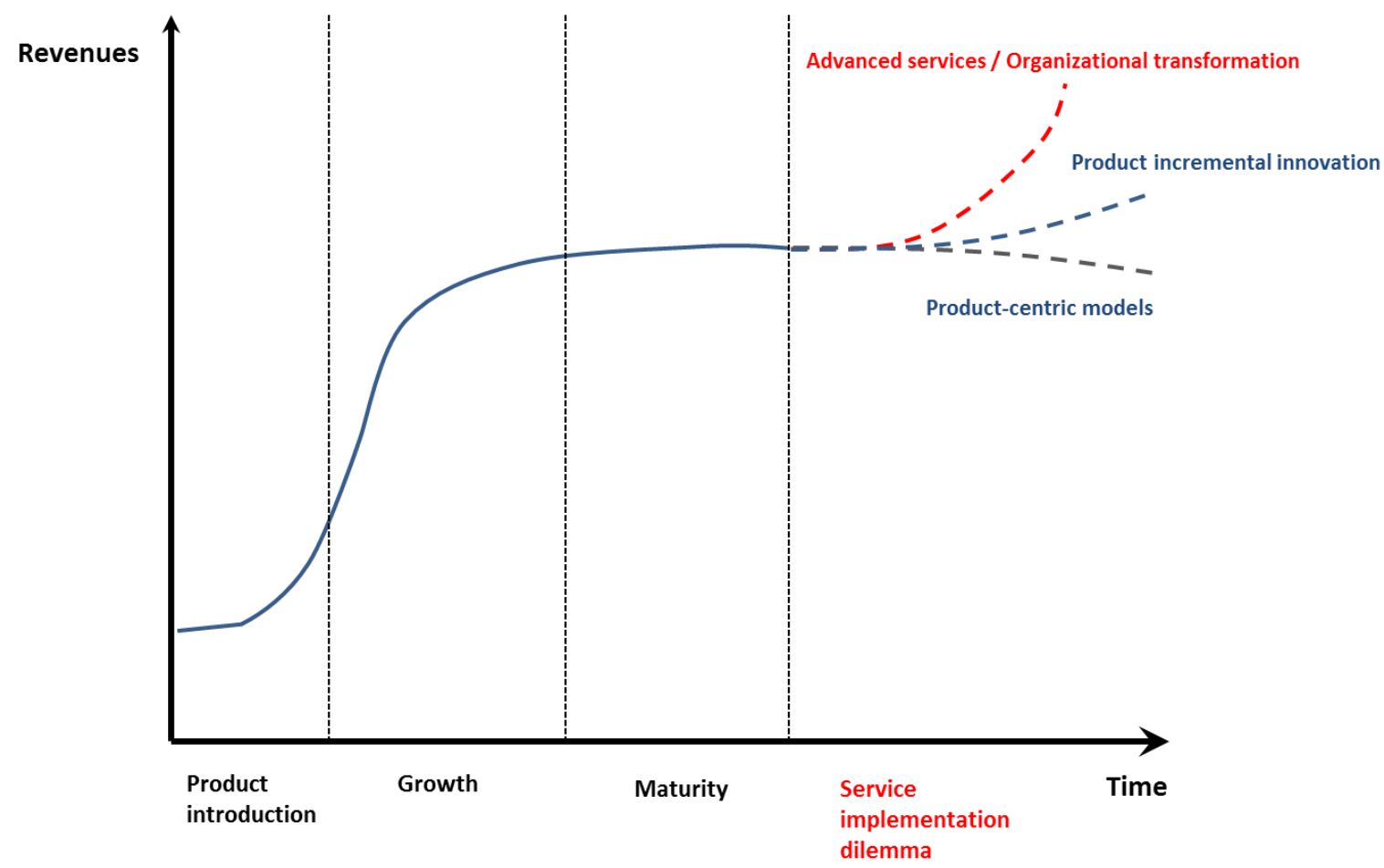

FIGURE 1 The service implementation dilemma

Although the literature on service implementation is growing fast, there is a lack of connection between the topics analysed by scholars and those that are of relevant for practitioners (Baines et al., 2017). The current academic literature on servitization and advanced services describes the phenomenon, provides some theoretical grounding, tests the relationship between service implementation and firm performance, and relates this strategy to a number of external and internal factors (Neely, 2008; Visnjic and Van Looy, 2013; Visnjic et al., 2015; Crozet and Millet, 2017; Kowalkowski et al., 2017). What practitioners are looking for, in contrast, relate to the challenges linked to the organisational change that a service strategy entails; the stages they need to follow, and what they should expect in each stage. Executives of product-focused manufacturers are eager to understand both the processes underlying the development, acquisition and exploitation of additional service capabilities and the different transformation trajectories that can boost the product-installed base value through the exploitation of service capabilities (Lee et al., 2016). With a few exceptions (Baines et al., 2017), the research community has not yet analysed the topic of organisational transformation 
in servitization. This special issue attempts to fill this gap. In preparing this, we have considered over fifty submissions and from these selected fourteen articles on a wide range of issues related to service implementation in manufacturing. Overall, the papers selected for publication in this issue contribute to understanding the manufacturers' context, the servitization journey followed, and the outcomes of the servitization change processes.

This editorial note provides an opportunity to position these contributions. To achieve this we first review crucial transformation frameworks, reflecting on the recent literature on servitization. We then provide an overview of contributions that increase understanding of service implementation as a process of organisational change, followed by the implications of the overview and suggestions for future lines of research.

\section{Service implementation and organisational transformation frameworks}

Servitization has been analysed as a process of transformation using different frameworks. Martinez et al. (2010) -updating previous frameworks from Davies (2003), Oliva and Kallenberg (2003), Tukker (2004), and Araujo and Spring (2006) - argue that servitization is a continuum ranging from product with services as add-on's to complex firms' product-service offerings. The servitization continuum can be represented through four different stages related to the customer-supplier interactions, starting with primarily transactional interactions, followed by product-plus-service offerings and subsequent customisation of product and service bundles. The service continuum concludes with the development of product-plusservice solutions co-designed with customers. Building on the same line of thinking, the more recent work of Parida et al. (2014) outlines critical competencies and learning processes to transform product-based organisations to undertake service business models successfully. These critical competencies include add-on services, maintenance/repair and product-support services, research and development activities, and functional and operational services.

Baines and Lightfoot's (2013) framework further develops these initial archetypal models of service transformation by including the service capabilities required for overcoming the various critical junctures that firms face in the servitization journey. The framework contains a detailed description of the servitization roadmap to develop advanced services (solutions, outcome-based services, etc.), based on three stages. As depicted in Figure 2, this process of organisational change is routed from businesses' engagement with product manufacturers to development of service-led competitive strategies while maintaining product economies of 
scale and scope, and ultimately the delivery of capabilities as an outcome, enabling a firm to achieve a unique competitive position.

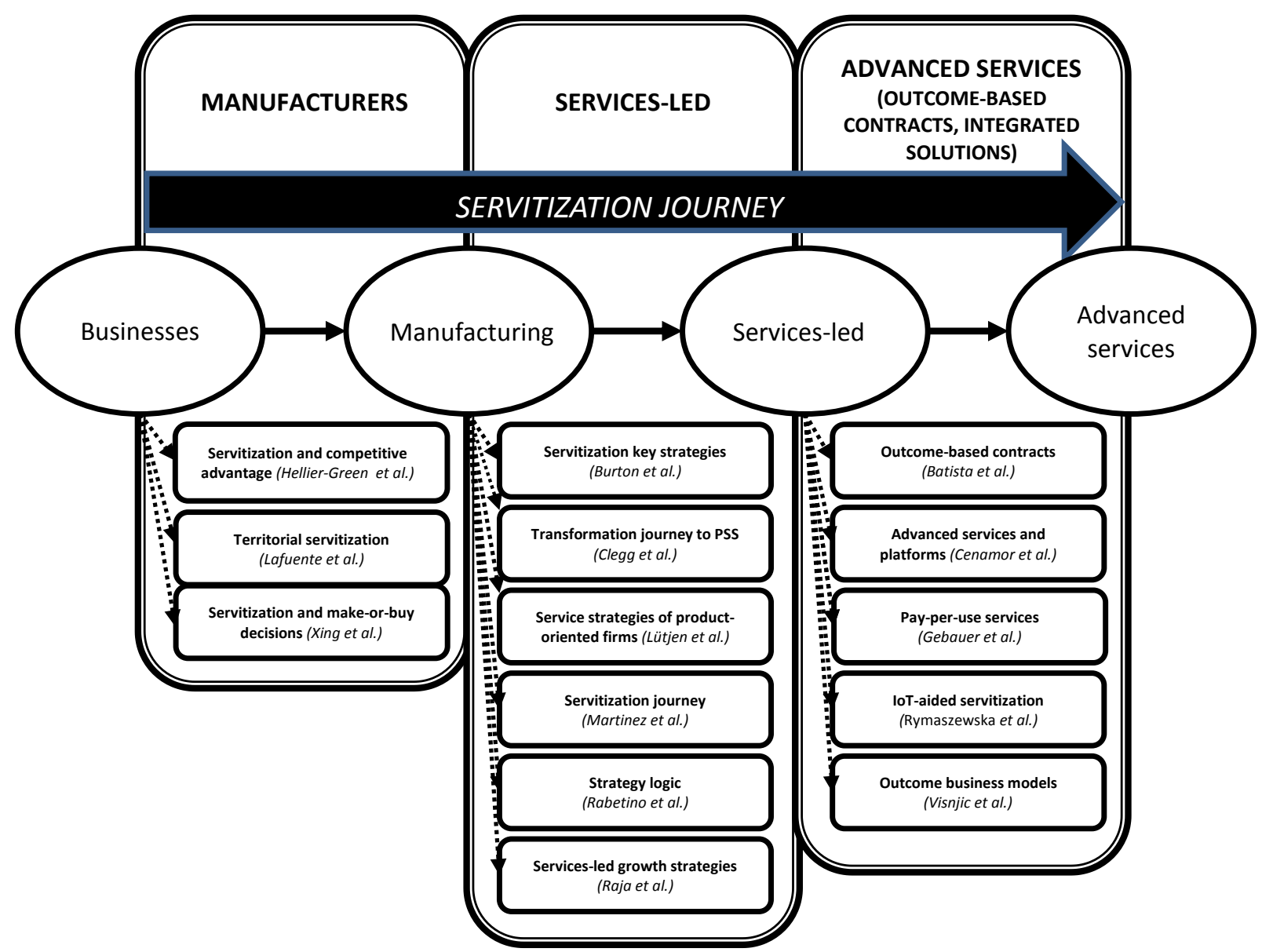

FIGURE 2 Roadmap of servitization (Source: Adapted from Baines and Lightfoot, 2013)

We use this framework to organise the contributions of this special issue on servitization transformation. The articles by Hellier-Green et al., Lafuente et al., and Xing et al. in this special issue focus on how manufacturers leverage their service transformation relative to external businesses. In this vein, Hellier-Green et al. show that manufacturers must consider the role of the service business before journeying to services. Lafuente et al. show the importance of collaborations between service businesses and manufacturers located in the same region, and Xing et al. describe how Chinese manufacturers use cross-border mergers and acquisitions (M\&As) to start the servitization journey.

Other articles in the special issue focus on the development of service-led competitive strategies. Whilst the articles by Burton et al., Clegg et al., Lütjen et al., Martinez et al., and Raja et al. study critical service-led strategies, the paper by Rabetino et al. describes manufacturers' strategy logic to continue toward successful servitization transformation. 
Finally, another group of articles (Batista et al., Cenamor et al., Gebauer et al., Rymaszewska et al., and Visnjic et al.) analyses how to implement a model successfully based on delivery of service capabilities as an outcome.

Baines et al. (2017) have recently developed a conceptual framework to support practitioners in the organisational transformation process underlying servitization. According to these authors, as depicted at the top of Table 1, there are three critical aspects in this process: the context of the servitization change, the process of servitization, and the outcomes obtained from this process. The papers selected for this special issue include significant contributions uncovering the organisational change process in product firms implementing advanced services/integrated solutions. Table 1 classified the contributions according to Baines et al.'s framework.

TABLE 1 Servitization transformation

\begin{tabular}{|c|c|c|c|c|c|}
\hline & & \multicolumn{2}{|c|}{$\begin{array}{l}\text { CONTEXT OF THE } \\
\text { CHANGE }\end{array}$} & $\begin{array}{c}\text { PROCESS OF THE } \\
\text { CHANGE }\end{array}$ & $\begin{array}{l}\text { OUTCOMES } \\
\text { OF CHANGE }\end{array}$ \\
\hline \multirow{4}{*}{ 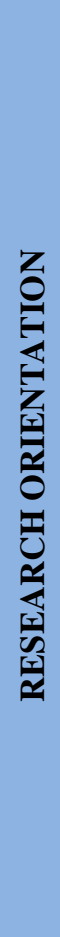 } & & External & Internal & \multirow[b]{2}{*}{$\begin{array}{c}\text { Advanced services } \\
\text { implementation through } \\
\text { platforms } \\
\text { (Cenamor } \text { et al.) } \\
\text { Transformation journey } \\
\text { to PSS } \\
\text { (Clegg et al.) } \\
\text { Servitization journey } \\
\text { (Martinez et al.) } \\
\text { IoT-aided servitization } \\
\text { transformation } \\
\text { (Rymaszewska } \text { et al.) }\end{array}$} & \multirow{2}{*}{$\begin{array}{c}\text { Outcome-based } \\
\text { contracts } \\
\text { (Batista et al.) } \\
\text { Strategy logic } \\
\text { (Rabetino et al.) }\end{array}$} \\
\hline & לָר & $\begin{array}{l}\text { Servitization and make- } \\
\text { or-buy decisions } \\
\text { (Xing } \text { et al.) }\end{array}$ & & & \\
\hline & & External & Internal & \multirow{2}{*}{$\begin{array}{c}\text { Service strategies of } \\
\text { product-oriented firms } \\
\text { (Lütjen et al.) } \\
\text { Service-led growth } \\
\text { strategies } \\
\text { (Raja et al.) }\end{array}$} & \multirow[b]{2}{*}{$\begin{array}{c}\text { Pay-per-use } \\
\text { services } \\
\text { (outcome-based } \\
\text { contracts) and } \\
\text { competitive } \\
\text { advantage } \\
\text { (Gebauer et al.) } \\
\text { Outcome } \\
\text { business models } \\
\text { (Visnjic et al.) }\end{array}$} \\
\hline & לָ & $\begin{array}{l}\text { Interaction between } \\
\text { manufacturing and } \\
\text { KIBs (Lafuente et al.) }\end{array}$ & $\begin{array}{c}\text { Key servitization } \\
\text { strategies } \\
\text { (Burton } \text { et al.) } \\
\text { Servitization } \\
\text { approaches and } \\
\text { competitive advantage } \\
\text { (Hellier-Green } \text { et al.) }\end{array}$ & & \\
\hline
\end{tabular}

Source: Adapted from Baines et al. (2017)

We first provide an initial rationale for the categorisation of the papers. The next section provides a more in-depth description of the different papers and how they are linked to the organisational change process. Burton et al., Hellier-Green et al., Lafuente et al., and Xing et al. analyse organisations' specific context when they began the servitization journey, reporting 
valuable advice about when and how service-oriented organisational change should take place. Cenamor et al., Clegg et al., Lütjen et al., Martinez et al., Raja et al., and Rymaszewska et al. describe different trajectories followed by organisations in the servitization process, giving substantial examples and advice to support the transition to implementation of advanced services and integrated solutions. Lastly, Batista et al., Gebauer et al., Rabetino et al., and Visnjic et al. explain the outcomes of the servitization transformation process, providing crucial indications about what should be changed at the network, corporate, business, and functional levels for a successful servitization journey.

The next section elaborates further on how the articles published in this special issue fit into the framework published in Baines et al. (2017), improving understanding of organisational transformation in service implementation. The paper summaries are categorised using the categories and headings shown in Table 1.

\section{Positioning articles in this special issue}

\subsection{Context of servitization change}

\subsubsection{Servitization and make-or-buy decisions}

Increasing global competition in product markets pushes firms to analyse achievement of competitive advantage through provision of services (Vandermerwe and Rada, 1988). This product-service innovation process requires understanding of the firm's capacity to implement services in-house, or whether they must "buy" these services in the form of collaborative partnerships (Mathieu, 2001). Buying options include M\&As and alliances in the form of partnerships with knowledge intensive business services (KIBs), which, according to Muller and Zenker (2001, p. 2), "can be described as firms performing, mainly for other firms, services encompassing a high intellectual value-added".

Some manufacturing firms compete worldwide, and for those companies service innovation is developed in-house in some countries and through collaborative partnerships in others. These decisions depend on different factors, such as technology maturity, regulatory contexts, influenced by the conditions of the specific competitive environment (Bustinza et al., 2017). In this context, M\&As are a primary entry mode in international markets. Xing et al. analyse a set of servitization strategies used in cross-border M\&As, proposing a typology of strategies based on the prior level of services offered by both the acquiring and the target firm. This typology analyses how servitizing firms are adding, utilising and reconfiguring their 
resources and capabilities, while using absorptive capacity and integration mode choices as critical variables that influence development of overall service capability.

\subsubsection{Interaction between manufacturing and KIBS}

Large manufacturing firms may tend to develop service innovation in-house (Bustinza et al., 2017), as they have organisational resources to deal with the market and technological uncertainty underlying service innovation development (Keupp and Gassman, 2009). KIBS are defined as professional service firms that develop advanced services primarily for small and medium-sized (SMEs) manufacturing firms (Muller and Zenker, 2001). Policy makers can thus help product-based SMEs by encouraging interaction with KIBs, thereby contributing to the development of new projects and the creation of jobs that ultimately will enhance territorial competitiveness.

Lafuente et al. analyse the renaissance of local manufacturing sectors by studying role of local KIBs in increasing competitiveness and employment at a territorial level, subsequently producing a virtuous circle defined as "territorial servitization". These results are in line with Kamp and Ruiz de Apodaca (2017), who show how the interaction between manufacturing firms and KIBS increases total exports and turnover on a regional level. This line of research on the effect of territorial servitization is important, as it ultimately provides policy tools to regional and national governments to stimulate service innovation in the region.

\subsubsection{Key servitization strategies}

Prior studies have identified the challenges manufacturers face in undertaking the servitization journey (Martinez et al., 2010; Benedettini et al., 2015). How a manufacturer's service strategy addresses these challenges is a relatively underexplored topic, however. Illuminating this issue requires learning from unsuccessful cases (Baines and Lightfoot, 2013). Analysing how some firms have failed to respond to servitization challenges has generated a debate around the process of deservitization of manufacturing firms (Kowalkowski et al., 2017). Burton et al. analyse the connections between challenges and a set of service strategies adopted by four manufacturers to identify why firms may fail when they introduce services in their offerings.

Recent studies recognize that manufacturing firms follow different strategies in adopting servitization (Lee, Yoo, and Kim, 2016), indicating that service implementation challenges can be overcome in different ways. The contribution of Burton et al. is to align the new service 
development (NSD) process to manufacturers' service strategies, resulting in seven different propositions. These propositions provide some theoretical grounding on the relevance of developing service capabilities, customer feedback and engagement, and interconnectivity. The paper also views scalability as necessary for extracting value from service implementation, encouraging product firms to invest in flexible people and modularisation.

\subsubsection{Servitization approaches and competitive advantage}

Manufacturing organisations seek to improve their competitive advantage through provision of services. Their rationale is the differentiation obtained through tailored value propositions that shift from traditional transactional exchange to a longitudinal relationship with the customer (Bustinza et al., 2017). This paradigm shift that servitization creates has been analysed in two parallel streams of manufacturing literature: goods-dominant (G-D) logic, where services are an add-on to products; and service-dominant (S-D) logic, where offerings are designed by incorporating both the firm's and the customer's resources to co-create value through services in use contexts. Hellier-Green et al. explain the conceptual differences between these approaches to servitization, providing guidance on which approach is most appropriate, depending on a firm's mind-set. Firms should follow a G-D logic when their value propositions have embedded value. Service is a bolt-on, the servitization journey is linear, risk is linked to service content, and variety is limited to low contexts of use. S-D logic should be considered when the customer is highly engaged, value-in-use is co-created, and variety related to contexts of use is high. The authors conclude that the two approaches are not necessarily mutually exclusive, explaining useful examples applied in different industries.

\subsection{Process of the change to servitization}

\subsubsection{Advanced services implementation: platform architecture in servitization}

Servitization affects different processes, with digitalisation as an enabler facilitating process transformation. Digitally-enabled servitization is based on leveraging the value of digital technologies for advanced services implementation. Information gathered by these technologies is a key driver of success for servitization transformation. The role of technology is an increasingly important sub-theme analysed in studies of advanced services known as digital servitization (Vendrell-Herrero et al., 2017). Within this research line, platform configurations based on the information gathered by technological devices can facilitate coordination between activities inside the firm, i.e., between $R \& D$ activities and market and sales units (Silvestro and Luastro, 2015). 
Cenamor et al. pinpoint the value of platform analysis in the context of advanced services implementation. For these authors, service implementation must seek both operational efficiency and customization by leveraging information modules. Information gathered helps back-end and front-end units to orchestrate and build the development, configuration and delivery of offerings. This platform approach optimizes processes while increasing operational efficiency, enabling flexible and customized offerings. As a consequence, manufacturing firms can adopt a platform approach to mitigate service paradox, that is, those cases of companies that, after transiting into services, do not get the expected higher returns due to both cultural and organisational impediments (Gebauer et al., 2004). To overcome servitization challenges, firms must enrich manufacturing value propositions through digital services while containing costs.

\subsubsection{The servitization journey}

In examining interactions with the environment, the literature shows that servitization assumes a continuous process of organisational change (Baines et al., 2017). A firm's adaptation model must continually address the challenges and incorporate the enablers of servitization. The literature on servitization has usually analysed this topic through case studies or cross-sectional analyses, but less frequently in longitudinal studies. Martinez et al. provide an original view using the former methodological approach for illustrating product firms' journey to service implementation. Their findings support the idea that servitization follows a model of continuous change rather than a punctuated equilibrium. Following this premise of a continuum, the literature traditionally offers two strategic options linked to deliberate and emergent/contingency strategies, respectively (Mintzberg and Waters, 1985). Martinez et al. support the emergent contingency strategy approach to handle the servitization process.

The traditional servitization journey has been established following three continuous stages that incorporate three categories of services: basic, intermediate, and complex or advanced (Baines and Lightfoot, 2013). Martinez et al. analyse the coexistence of different categories of services, presenting three plausible journeys to services considering the role of technology, maturity of firms and environmental context. The authors' pioneering findings identify seven stages of the service strategy model for consideration by product firms seeking to servitize.

\subsubsection{IoT-aided servitization transformation}

The Internet-of-Things (IoT) is an emerging topic in the analysis of digitally-enabled servitization. Basically, IoT enables tracing of the interactions between a multitude of 
heterogeneous physical objects, providing real-time state and visibility of product use (Parry et al., 2016). This technological breakthrough has the potential for product-service development in different industries. Clegg et al. and Rymaszewska et al. address the question of the role of the IoT in improving servitization transformation.

Technology reshapes the nature of strategies and competition (Porter and Heppelmann, 2015). Implementation of IoT solutions allows firms to increase service-led strategic options, generating IT-driven servitization. Clegg et al. define the collection of enterprise modules -aids by the implementation of IT- working together to deliver Product-Service solutions. Rymaszewska et al. state that IoT-aided servitization is a particular link channel. In addition to actively engaging customers in value co-creation processes ( $\mathrm{Ng}$ et al., 2009), this link provides the best level of services to satisfy customers' needs. As a result, IoT aids servitization transformation, as it increases opportunities for value creation based on the new and tailored services created from the customer information collected.

\subsubsection{Service strategies of product-oriented firms}

Firms must cope with different barriers and/or challenges along the product-service continuum (Baines and Lightfoot, 2013). This continuum includes different stages related to the service provision category; each transition from one stage to another requires shifting service strategies (Tukker, 2004). Nevertheless, firms develop different types of services simultaneously (for instance, both intermediate and advances services), resulting in different service trajectories that coexist with different service strategies (Raddats and Kowalkowski, 2014). Lütjen et al. propose analysing service trajectories and strategies together through the lenses of service innovation. Service innovation trajectories encompass service-related dimensions - type of services and innovation-related dimensions, $R \& D$ investments, source of innovation and service innovativeness - to describe three different pathways to servitization: highly commodity-oriented, towards-servitization, and highly service-oriented trajectories. Each trajectory faces different barriers. For example, the highly commodity-oriented trajectory relates prevailing barriers to strategy fit, whereas market-related barriers prevail for the highly service-oriented service innovation trajectory. Overall, Lütjen et al. advise managers to develop a clear strategic intent while increasing organisational flexibility, performing ongoing analysis of systematic service implementation to enhance organisational ambidexterity.

\subsubsection{Organisational capabilities and servitization: service-led growth strategies}


Manufacturers adopt service-led strategies to expand their traditional businesses into new business models containing a variety of value capturing processes (Visnjic et al., 2013). Organisational transformation begins by developing R\&D service functions while contemplating how to scale these services up for production. Raja et al. propose three different trajectories for developing new solution-based business models that incorporate services: serviceability, scalability and solutions trajectories. The serviceability trajectory involves providing customers with outcome-based business models, whereas scalability relates to the firm's capacity to integrate service successfully in current production lines. Solutions go further than previous trajectories, enabling customers to outsource their operations as manufacturer needs, integrating the customer's processes to customise solutions effectively.

Raja et al. argue that manufacturers need relational, learning and development capabilities to provide customised solutions effectively. These capabilities will help them to deal with serviceability and the dilemma of closeness, i.e. that customers are reluctant to grant access to critical information; with scalability and the dilemma of technological simplification, i.e. achieving scale through simplified processes without losing some elements of distinctiveness; and with solutions and the dilemma of organisational capabilities, i.e. the extent to which new capabilities influence or are influenced by established capabilities. Manufacturing firms are challenged to manage and respond to these dilemmas by developing appropriate capabilities on a regular basis.

\subsection{Outcomes of servitization change}

\subsubsection{Outcome-based contracts}

There is general consensus that servitization involves significant challenges for manufacturers and that it develops organisational capabilities. Nevertheless, there is not yet an agreement on how these capabilities should be named; e.g. outcome/output-based capabilities (Ng, Maull, and Yip, 2009; Ulaga and Reinartz, 2011) or advanced services capabilities (Baines and Lightfoot, 2013). These capabilities are delivered by the performance of products when services are implemented. For Batista et al., outcome-based contractual interactions can help to develop co-capabilities between provider and customer organisations, enabling the achievement of outcomes by systems as a hole.

Batista et al. use a systems perspective to analyse how advanced services enhance both manufacturer and customer capabilities. This perspective enables understanding of how 
different parts can work together as a whole, as well as the importance of contextual variations originated by the external environment. Further, this perspective requires a mind-set change from a merely transactional to a relational view of process. Relational process benefits customers, as it reduces problems of variety that arise in the external environment, thus decreasing the development risk of a project and increasing its viability. Finally, the authors suggest that the system's purpose should be the primary boundary consideration, which is not necessarily restricted to firm boundaries.

\subsubsection{Strategic logic: strategic servitization transformation}

As servitizing organisations shift their focus from products to a combination of integral customer solutions, this paradigm shift must be supported by a strategic logic that incorporates all supportive processes involved and assets to be realigned. Basically, the key processes and practices must be monitored for successful implementation of a service strategy (Opresnik and Taisch, 2015). During servitization transformation, the firm realigns processes, resources and capabilities, value propositions, and financial expectation. This transformation affects the different organisational levels or strategy map perspectives responsible for translation of the servitization's strategic vision into appropriate choices.

Rabetino et al. characterise the strategies associated with servitization in terms of financial value propositions and attributes, internal operations, customer management and innovation processes, and learning and growth perspectives. Based on these different perspectives, the authors propose a strategy map of servitization, surveying critical productivity and growth strategies that incorporate short-to-long-term objectives. The authors thus identify the components linked to servitization strategy, improving knowledge of the relationships between the different processes involved.

\subsubsection{Organisational and service capabilities for achieving competitive advantage}

Organisational capabilities result from integration of individual knowledge across different firm functions and levels of hierarchy (Zander and Kogut, 1995), generating competitive advantage when converted into distinctive capabilities (Wernerfelt, 1984) or core competencies (Prahalad, 1993). Product-oriented firms must integrate service knowledge across the abovementioned organisational functions and hierarchy to develop service capabilities, including relational capabilities for capturing implementation of service strategies and other organisational capabilities for appropriate strategy formulation. 
Gebauer et al. describe the set of organisational capabilities required for pay-per-use services, an alternative nomenclature for outcome-based contracts. The authors analyse different organisational functions ( $R \& D$, production, sales, service, financing and purchasing) and hierarchical levels (individual, task-specific, specialised, activity-related, functional and cross-functional capabilities) for uncovering the core competencies needed for pay-per-use services. Competitive advantage is achieved through the specific organisational capabilities related to financing, aligning costs and equipment use, and effectively collaborating with customers. Finally, Gebauer et al. propose that utilising technologies, strategising and derisking pay-per-use services are core competencies needed to sustain competitive advantage.

\subsubsection{Value creation: outcome business models}

Servitization shapes organisational business models to incorporate service innovation. It is thus an organisational transformation from a product-based business model to adoption of service-enabled-capability or outcome-based business models (OBM). OBMs are responsible not just for coordinating the activities needed but also for delivering the outcomes contracted. While new business models are changing the drivers of value creation, the specific drivers of value creation in OBMs are still underexplored. Analysing these value drivers is precisely the research aim of Visnjic et al., who categorise the value drivers into five types under the acronym CLEAN (complementarity, lock-in, efficiency, accountability and novelty). The framework contains novel insights, such as the category "accountability value", which is responsible for minimising risks and internalising uncertainties. Finally, the authors identify synergies between some of the value-driver categories, which can thus enable low-cost variability based on customer data use (Porter and Heppelmann, 2015).

\section{The servitization journey: reflections and future avenues of research}

From the analysis undertaken in the previous sections, we identify four emerging themes in the organisational transformation of product firms implementing services: i) assessment of make-or-buy decisions, ii) development of strategic approaches, iii) implementation of digital technologies and platforms, and iv) advantages and disadvantages of outcome-based contracts. All of these interconnected themes are the subjects underlying development of future research avenues.

An interesting, yet underexplored research avenue is the analysis of strategic concentric partnerships with KIBS. Collaboration with external partners who have extensive experience in 
technological upgrading provides the possibility of offering bundles of products and services without the need for large investments and transformations (Baines et al., 2017). On the negative side, those undertaking such partnerships must be aware that partners may increase their market capacity, influencing the product firms' future market positioning and prospects for profit.

Strategic partnerships are particularly important for service implementation in large manufacturers (Paiola et al., 2013; Bustinza et al., 2017), but the impact of cross-sector partnerships for small and medium manufacturers has not been analysed yet. Interestingly, in this special issue it is emphasised that strategic partnerships are important for SMEs as partnerships may be a suitable strategic choice for product firms with scarce resources that aim to servitize (Lafuente et al.; Rabetino et al.). This opens a further research avenue measuring firm (micro) and territorial (meso) level benefits obtained from the collaboration between product and service SMEs.

If we advance along the service continuum, internationalisation of the service function is an important strategic decision (Vandermerwe and Rada, 1988; Baines et al., 2017); establishing and strengthening links with foreign customers may be a decisive element in the successful implementation of services. Common strategic approaches to entry foreign markets are M\&As and strategic partnerships with foreign KIBS. To date the literature is silent on internationalization of the service function, an issue we consider of vital importance to better understanding the organisational transformation of many industrial companies.

As to strategic approaches, another important debate involves the theoretical foundations for analysing the phenomenon of servitization. In the current special issue, the strategic theories used relate primarily to the resource-based view (Wernerfelt, 1984) and S-D logic (Vargo and Lusch, 2004). Other growing fields in business strategy seem able, however, to provide different and important theoretical groundings for servitization. We highlight two: strategy as practice and firm agility. Nordin and Ravald (2016) explain how servitization practitioners handle collaborative B2B relationships in practice. They view managers' behaviours as crucial and thus advocate a 'strategy-as-practice' research approach. This practitioner's perspective opens up an interesting research line on behaviours, activities and critical factors affecting service implementation in manufacturing contexts (Holmlund, Kowalkowski, and Biggemann, 2016; Kohtamäki and Rajala, 2016). Equally important, strategic agility is essential for adjusting the company's strategic direction in an ongoing and continuous process (Weber and 
Tarba, 2014). This research line, as well as the practitioners' approach, will help managers seeking to servitize.

Another important element related to the organisational transformation underlying technological change is the management of information flows and decision-making processes. According to Kim, Park, and Prescott's (2003) framework, firms developing services must have a different structure than firms developing products. Kim et al.'s model predicts that firms developing services must centralise information flows and decision making so that they can engage with customers consistently, whereas firms developing products (i.e., R\&D) must decentralise processes, as access to information at all organisational levels is an important factor for obtaining more innovative products. This means that, at a time when multinationals are decentralising information flow, firms developing processes might need to reconsider these movements if they are developing services. This is a topic is of great importance to which the research community should pay attention.

The outcome-based contract literature clearly indicates the importance of capturing value during the entire product lifecycle ( $\mathrm{Ng}$ et al., 2009). Such capture requires a close, long-term relationship with the customer and a process of value co-production. This process can be overcomplicated when a third party, the KIBS that have established a strategic partnership with the product firm, enters the game. One interesting path of research inquiry is to identify case studies in which three parties (manufacturer, KIBS and clients) enter into a long-term contractual relationship based on outcome-based contracts. In addition, the literature on outcome-based contracts is largely qualitative, as longitudinal data for a representative number of firms undertaking this specific business model may not be available. When outcome-based contracts gain popularity and data become more available, research should investigate the assessment of these contracts, and how gaining revenues through a relational approach provides longer-term profits rather than gaining revenues through a one-shot transaction.

\section{Concluding remarks}

Manufacturing organisations face significant challenges during the organisational change required to implement service innovations. Managers and practitioners increasingly demand prescriptive research to overcome these challenges, barriers and organisational inertia. This special issue contributes to guiding firms on the context, process and outcomes of the servitization journey, particularly on topics such as make-or-buy decisions, development of 
service strategies, implementation of digital technologies and capabilities generated by advanced services implementation and outcome-based contracts. Remarkably, interesting and challenging research lines arise from make-or-buy variables related to the servitization process, service trajectory analysis, and strategy-as-practice from a managerial perspective.

\section{References}

Araujo, L. and Spring, M. (2006). Service, product, and the institutional structure of production. Industrial Marketing Management, 35(7), 797-805.

Baines, T. and Lightfoot, H. (2013). Made to serve: how manufacturers can compete through servitization and product service systems. Chicester, UK: John Wiley \& Sons.

Baines, T., Ziaee Bigdeli, A., Bustinza, O. F., Shi, G., Baldwin, J. S., and Ridgway, K. (2017). Servitization: revisiting the state-of-the-art and research priorities. International Journal of Operations \& Production Management, 37(2), 256-278.

Benedettini, O., Neely, A., and Swink, M. (2015). Why do servitized firms fail? A risk-based explanation. International Journal of Operations \& Production Management, 35(6), 946-979.

Bustinza, O. F., Gomes, E., Vendrell-Herrero, F., and Baines, T. (2017). Product-service innovation and performance: the role of collaborative partnerships and R\&D intensity. $R \& D$ Management, In Press.

Crozet, M. and Milet, E. (2017). Should everybody be in services? The effect of servitization on manufacturing firm performance. Journal of Economics and Management Strategy, In Press.

Cusumano, M. A., Kahl, S. J., and Suarez, F. F. (2015). Services, industry evolution, and the competitive strategies of product firms. Strategic Management Journal, 36(4), 559-575.

Davies, A. (2003). Integrated solutions: the changing business of systems integration, in Prencipe, A., Davids, A. and Hobday, M. (Eds), The Business System Integration. Oxford, UK: Oxford University Press.

Financial Times (2017). Why Germany needs to accelerate into the digital fast lane. Accessed from: https://www.ft.com/content/31469796-dcd1-11e6-9d7c-be108f1c1dce

Gebauer, H., Fleisch, E., and Friedli, T. (2004). Overcoming the service paradox in manufacturing companies. European Management Journal, 23(1), 14-26.

Gebauer, H., Ren, G. J., Valtakoski, A., and Reynoso, J. (2012). Service-driven manufacturing: provision, evolution and financial impact of services in industrial firms. Journal of Service Management, 23(1), 120-136.

Holmlund, M., Kowalkowski, C., and Biggemann, S. (2016). Organisational behavior in innovation, marketing, and purchasing in business service contexts: an agenda for academic inquiry. Journal of Business Research, 69(7), 2457-2462. 
Kamp, B. and Ruiz de Apodaca, I. (2017). Are KIBS beneficial to international business performance: evidence from the Basque Country. Competitiveness Review: An International Business Journal, 27(1), 80-95.

Keupp, M. M. and Gassmann, O. (2009). Determinants and archetype users of open innovation. $R \& D$ Management, 39(4), 331-341.

Kim, K., Park, J. H., and Prescott, J. E. (2003). The global integration of business functions: a study of multinational businesses in integrated global industries. Journal of International Business Studies, 34(4), 327-344.

Kindström, D. (2010). Towards a service-based business model: key aspects for future competitive advantage. European Management Journal, 28(6), 479-490.

Kohtamäki, M. and Rajala, R. (2016). Theory and practice of value co-creation in B2B systems. Industrial Marketing Management 56, 4-13.

Kowalkowski, C., Gebauer, H., Kamp, B., and Parry, G. (2017). Servitization and deservitization: overview, concepts, and definitions. Industrial Marketing Management 60, 4-10.

Lee, S., Yoo, S., and Kim, D. (2016). When is servitization a profitable competitive strategy?. International Journal of Production Economics, 173, 43-53.

Lee, K. and Malerba, F. (2017). Catch-up cycles and changes in industrial leadership: windows of opportunity and responses of firms and countries in the evolution of sectoral systems. Research Policy, 46(2), 338-351.

Mathieu, V. (2001). Service strategies within the manufacturing sector: benefits, costs and partnership. International Journal of Service Industry Management, 12(5), 451-475.

Martinez, V., Bastl, M., Kingston, J., and Evans, S. (2010). Challenges in transforming manufacturing organisations into product-service providers. Journal of Manufacturing Technology Management, 21(4), 449-469.

Mintzberg, H. and Waters, J. A. (1985). Of strategies, deliberate and emergent. Strategic Management Journal, 6(3), 257-272.

Muller, E. and Zenker, A. (2001). Business services as actors of knowledge transformation: the role of KIBS in regional and national innovation systems. Research policy, 30(9), 1501-1516.

Neely, A. (2008). Exploring the financial consequences of the servitization of manufacturing. Operations Management Research, 1(2), 103-118.

Ng, I. C., Maull, R., and Yip, N. (2009). Outcome-based contracts as a driver for systems thinking and service-dominant logic in service science: evidence from the defence industry. European Management Journal, 27(6), 377-387.

Nordin, F. and Ravald, A. (2016). Managing relationship gaps: a practitioner perspective. Journal of Business Research, 69(7), 2490-2497.

Paiola, M., Saccani, N., Perona, M., and Gebauer, H. (2013). Moving from products to solutions: strategic approaches for developing capabilities. European Management Journal, 31(4), 390-409. 
Parida, V., Sjödin, D. R., Wincent, J., and Kohtamäki, M. (2014). Mastering the transition to productservice provision: insights into business models, learning activities, and capabilities. ResearchTechnology Management, 57(3), 44-52.

Parry, G. C., Brax, S. A., Maull, R. S., and Ng, I. C. (2016). Operationalising IoT for reverse supply: the development of use-visibility measures. Supply Chain Management: An International Journal, 21(2), 228-244.

Porter, M. E. and Heppelmann, J. E., 2015. How smart, connected products are transforming companies. Harvard Business Review, December, 96-112.

Prahalad, C. K. (1993). The role of core competencies in the corporation. Research-Technology Management, 36(6), 40-47.

Raddats, C. and Kowalkowski, C., 2014. A reconceptualization of manufacturers' service strategies. Journal of Business-to-Business Marketing, 21(1), 19-34.

Silvestro, R. and Lustrato, P., 2015. Exploring the "mid office" concept as an enabler of mass customization in services. International Journal of Operations \& Production Management 35(6), 866-894.

Suarez, F. F., Cusumano, M. A., and Kahl, S. J. (2013). Services and the business models of product firms: an empirical analysis of the software industry. Management Science, 59(2), 420-435.

Tukker, A. (2004). Eight types of product- service system: eight ways to sustainability? Experiences from SusProNet, Business Strategy and the Environment, 13(4), 246-260.

Ulaga, W. and Reinartz, W. J. (2011). Hybrid offerings: how manufacturing firms combine goods and services successfully. Journal of Marketing, 75(6), 5-23.

Vandermerwe, S. and Rada, J. (1988). Servitization of business: adding value by adding services. European Management Journal, 6(4), 314-324.

Vargo, S. L. and Lusch, R. F. (2004). Evolving to a new dominant logic for marketing. Journal of Marketing, 68(1), 1-17.

Vendrell-Herrero, F., Bustinza, O. F., Parry, G., and Georgantzis, N. (2017). Servitization, digitization and supply chain interdependency. Industrial Marketing Management, 60, 69-81.

Visnjic, I. and Van Looy, B. (2013). Servitization: disentangling the impact of service business model innovation on manufacturing firm performance. Journal of Operations Management, 31(4), 169180.

Visnjic, I., Wiengarten, F., and Neely, A. (2016). Only the brave: product innovation, service business model innovation, and their impact on performance. Journal of Product Innovation Management, $33(1), 36-52$.

Wall Street Journal (2017). GE, Siemens vie to reinvent manufacturing by harnessing the cloud. Accessed from: https://www.wsj.com/articles/ge-siemens-vie-to-reinvent-manufacturing-byharnessing-the-cloud-1488722402 
Weber, Y. and Tarba, S. Y. (2014). Strategic agility: a state of the art. California Management Review, $56(3), 5-12$.

Wernerfelt, B. (1984). A resource-based view of the firm. Strategic Management Journal, 5(2), 171180.

Zander, U. and Kogut, B. (1995). Knowledge and the speed of the transfer and imitation of organisational capabilities: An empirical test. Organisation Science, 6(1), 76-92. 